\title{
Mentally of Accounting in the Era of Indonesian Urban Society
}

\author{
Andrea Geovani and Erina Sudaryati \\ Airlangga University, Jl.Airlangga, Surabaya, East Java \\ andrea.vani06@gmail.com,erina.sudaryati@feb.unair.ac.id
}

Keywords: Mental Accounting, Urban Society, Pancasila.

\begin{abstract}
This paper aims to analyze and research the experts' thoughts which are spread in books, articles, documents, etc, about mental accounting in Indonesian urban society. In facing the rapid change of modernization, Indonesian society might need to redevelop mental accounting with re-addressing the national principle through interpreting accountancy with Pancasila as the national principle. Based on the result of the research on each precept, it can be obtained a conclusion that the definition of accounting in the perspective of Pancasila is human responsibility to God through humanizing human beings in the midst of the development of urbanization in Indonesia; creating a fraternal spirit among people in it; elevating people to an unqualified justice for anyone in the country; as well as balancing the physical and spiritual needs of human beings in terms of financial and economic activities that can advance the nation's life to be better and prosperous for all communities in it. Accounting in the perspective of Pancasila does not only emphasize the material element alone.
\end{abstract}

\section{INTRODUCTION}

The majority of Indonesian society is the result of uncontrollable urbanization as an effect of industrialization and commercialization in urban areas, especially big cities in Indonesia. Urban society is social creature that needs other people in their life; a group of people that need each other will form a together life which is called society. In urban society, globalization often shifts from agrarian society to industrial society, which therefore constructs urban life style, so that it creates consumerism. Consumerism results in pseudo necessities which can build a form of life style social control which is run by society in daily life. Indonesia, especially from the New Order which makes use of western technology and foreign capital which have produced new values in social life that shift traditional culture that has been adhered from long time ago (Heryanto, 2005). Along with the shifting of value, consumerism has as well spread to both rural areas and big cities in Indonesia. Life style is a characteristic of a modern world, so that everyone who lives in a modern society will use the notion of life style to describe both their own actions and other people in their life.

The life style variables are also known as psychographic characteristics since activities, interests, and opinion are psychographic orientation variables which could be quantified where life style factors which are relevant to the marketer can be seen from two levels (Ali, 2013). First, life style largely tends to change. Second, life style can be made as specific product determination basis. Indirectly, if humans' necessities are becoming more complex in their life, especially urban society with modern life style, it will surely be a high level of consumerism. Science and technology can be said as social activities processes which are highly influenced by the necessities and value system that lie in the society, so that its development is inseparable from the socio-cultural values that lie behind it (Armawi, 2007).

In urban life, the role of technology greatly influences the progress of urban society, so urban society is very dependent on electricity and technology. One of them is technology in the field of communication. Era of Fordism, it is a crucial point in the application of economical development technology, which is the massive commodity production offset by massive scale consumption (Jati, 2015). The massive consumption is due to the increasing of society's demand of commodities along with the increase in the quality of goods. Technology plays a role in increasing the added value of a product thereby increasing the allure of the public to buy it. In subsequent developments, the use of technology then evolves into social behavior and lifestyle for middle class groups. Ultimately, 
technology becomes a symbol for middle-class groups to differentiate themselves with other segments of society. However, it will have a negative impact with the danger of individuality or social autism when one is so dependent on the communication technology devices they own.

Consumerism in Indonesia is reinforced by the emergence of a new consumer class that is the emergence of expenditure they spend per day (Rosida, 2014). Consumerism that is currently a lifestyle of urban Jakarta cannot be separated from the culture of capitalism. They need the community to continue spending their money on their products. Without capitalism, consumerism will perish. Capitalistic creations, such as television commercials, is a community which inculcate a consumptive characteristic. Accounting is a science that is used every day and every moment in human life. Accounting science is used by any societies or institutions in the world. Accounting is a science that is useful for humans in achieving predetermined targets. Imagine what happens if it costs more than the benefits we use. But, with this modern age, we also need to prepare mental in facing this rapid development of the age.

This research is expected to give benefits to the development of accounting science, especially to grow mental accounting in the era of urban communities in Indonesia. Based on the result of the research on each precept, it can be obtained a conclusion that the definition of accounting in the perspective of Pancasila is human responsibility to God through humanizing human beings in the midst of the development of urbanization in Indonesia; creating a fraternal spirit among people in it; elevating people to an unqualified justice for anyone in the country; as well as balancing the physical and spiritual needs of human beings in terms of financial and economic activities that can advance the nation's life to be better and prosperous for all communities in it. Accounting in the perspective of Pancasila does not only emphasize the material element alone.

\section{METHODS}

A research is not possible to be conducted without any accompanying methods. Social sciences can be conceptualized through four assumptions of understanding related to the epistemological, axiological, ontological, and human nature (Burrell and Morgan, 2017). This research is based on the ontology aspect of the reality that happened in Indonesian urban society. This study looks at the events that occur by conducting a subjective observation by collecting facts that occur in the field.

The research used in this paper is a qualitative study based on the study of documents / texts. This study observes and examines the thoughts of the experts, whose thoughts are scattered in several books, articles, documents, etc about mental accounting. Qualitative research is a research that intends to understand the phenomenon which is experienced by the research subjects, such as behaviors, perceptions, motivations, actions, etc by describing in the form of words and language in a special context of scientific and by utilizing various methods that occur naturally (Bungin, 2005). Another consideration of researchers that use qualitative methods is because they are aware of its weakness that cannot be avoided or can be released in using this method.

In this study, the authors use the paradigm of postmodernism as the perspective of thought. The reason for using the paradigm of postmodernism is the writer's desire of not only criticizing the meaning, but also incorporating new values in that meaning.

\section{RESULTS AND DISCUSSION}

Most of the concepts in theories of the study of accountant are from other sciences, especially behavioral science. Behavioral science alone mostly refers to both psychological and sociological concepts related humans' daily life. The mental budget works when one can track the outcome and assign the account they have (Heath, 1995). Time becomes increasingly important to a person because "this is the scarcity that creates value". This scarcity of time has resulted in many technological advances for time efficiency, such as the use of washing machines and micro-wives, to dependence on fast food and concluded that time precious resource equal to money (Jacoby, Szybillo, and Berning, 1976). A mentally of accounting is a psychological account established by an individual to evaluate the costs and benefits of results that are then evaluated using prospecting theory principles (e.g. avoidance loss, risk seeking behaviors for loss etc. (Kahneman and Tversky, 1984).

Modern is a symbol of the abandonment of the non-modern past, into a better present (Mulawarman, 2014). The past attaches importance to the proximity of supernatural powers such as theology or religion, whereas the modern views the forces outside of man no longer plays a significant role in humans' life. Understanding modernity, like producing modern accounting today, is connoted as 
an "instrumental" process of the recording activity performed by a company. Pancasila explains the relationship between spirituality with ethics (Ludigdo and Kamayanti, 2012). By using Pancasila as the basis of accounting ethics code, Indonesia will also return to the roots of the state and liberate it from ethical imperialism. Accounting in general, is almost always connoted as an activity of recording and conveying financial information in the realm of a company's activities.

The abandonment of "God" in the world of science, because God, the religious values, and the human (subjective) soul that are the center and the meeting of God's "values" and the consciousness of the absolute truth of the scriptures, are no longer allowed into the universe realm and scientificallysocietal realities. Accounting (and Economics in it) is hand in hand to form a new theology, to the miraculous way of working the market through The Invisible Hand for prosperity, altering personal greed (seen in bottom line profitability, linearity equity, and progressive cash availability) to socialvirtue (common good), which lead to the rationality of science-technology developed for the benefit of profit.

Capitalism is the tip of the technical interest of positivism and empiricism that occurs in the real world. The continued impact of the multidimensional crisis is a crisis in developed countries such as the psychological crisis of poor fear, terrorism, alienation, dependence on drugs and technology, and others. The nature of accounting positivism is the attitude of individual life and hedonistic as well as materialistic lifestyles, the nature of sin thus makes human relationships be limited to mundane matters only and forget the existence of God that accompanies the life that occurred in this world (Achsin, 2006). In facing the rapid development of the modern era, perhaps Indonesian people need to re-grow mental accounting in the current era with being back of our country's philosophy, which is by interpreting accounting through Pancasila. The values found in Pancasila are an attempt to counter the imperialist attacks that are in fact the fruit of capitalism itself (Sitorus, 2015). Adoption of accounting based on the element of capitalism emphasizes the element of maintenance of power. The maintenance of power to God is Taqwa. Taqwa is a believer's awareness of God's presence in his other daily life and transactions with others (Iqbal and Mirakhor, 2011). Accounting is full of elements that are rational for the sake of business development, especially in the era of urban society which its development is increasingly rapid. Thus, accounting based on the influence of capitalism is full of masculinity elements. Definition of accounting based on the principle of God the Almighty is a process of human responsibility to God in terms of financial activities. In Islam, it is also written in the Qur'an.

"Truly the true religion of Allah is only Islam." (Quran Ali Imran: 19).

As a Muslim who believes in the holy book of the Qur'an, the first precept is tauhid, which believes that God is only one. Indonesia is a country with a variety of religions or pluralism state which also certainly believes that God is one and cannot be partnered. It refers to the command with believing in the essence of God by obeying all the commandments set by God. the first principle requires that there should be a divine value in the accountant's ethical code. In this case, with the life of capitalism in the era of increasingly advanced urban society, accountants who work need to pay attention to the codes of ethics that have been established (Ludigdo and Kamayanti, 2012). This is certainly necessary to avoid the occurrence of deviant behavior by taking into account the prevailing ethical code, so as to create honesty in the work. The definition of accounting based on the precepts of "Just and Civilized Humanity" is the process of humanizing human beings in terms of financial activity.

"Allah does not forbid you to do good and be fair to those who do not fight you because of religion and not (also) chase you away from your homes. Allah loves those who are fair ". (Quran Al Mumtahanah: 8).

In the economy of capitalism that occurs in urban society, it appears that everyone competes in business activities to earn maximum profit without being aware of the surrounding. Sometimes, this makes the assumption that the economic life which is happening is the rich who become richer and the poor who become poorer. In fact, this has been arranged in Pancasila that we need to be fair. In addition, in the Qur'an it has also been ordered to be fair to others. Business that occurs in the midst of technological advancement in the era of urban society sometimes makes urban communities forget the principle of justice to others, thus making the social gap in the community. In accounting, fair and honest attitude are needed in the process of recording and presenting process in financial statements in a company by not manipulating activities associated with accounting within a company. This does not fit the theory capitalism is identical with the pursuit of profit, and forever renewed profit, by means of continuous, rational, capitalistic enterprise (Weber, 2002). Accounting 
definition based on the precepts of "Unity of Indonesia" is the process of creating a spirit of brotherhood in terms of financial activities.

"O people, we have created you from a man and a woman, and We have made you nations and tribes to know one another. Surely your glory in Allah's sight is the more pious among you. Verily Allah is Knower, Most Thorough." (Quran Al Hujuraat: 13).

The life of urban people with tight routines certainly reduces the sense of concern for each other. Even in the economic life of capitalism, they are mostly just chasing profit. In the third principle of Pancasila, it is written "The Unity of Indonesia", whereas people should create a fraternal spirit, especially in terms of daily activities for financial activities. This certainly fosters the attitude of spirit among fellow citizens to increase the sense of unity in the life of this nation amid the changes that occur in the urban society in Indonesia. In the Qur'an, it has also been written that God creates human beings to get to know each other to create the mental accounting with a strong sense of unity in people's lives.

Definition of accounting based on the precept of "Democracy Led by the Wisdom of Deliberations among Representatives" is a process of raising people in terms of financial activities that occur in everyday life in society (Fishkin, 1991).

"And those who carry out the call of their Lord and perform the prayers, while their affairs are by deliberation between them and spend some of the sustenance We have given them." (Quran Ash Shura: 38)

In the capitalist economic system occurring in urban society, a company is owned by an individual whereas every individual is freed to possess all the wealth he has earned, resulting in personal satisfaction (Wallerstein, 1974). In the economy of capitalism in urban society, there is recognition of private rights, because the economy in it is governed by the occurring market mechanism, so that people are only always pursuing self-benefiting interests alone. Sometimes, this system does not benefit the community as a whole, especially people with lower economic condition. In fact, in the fourth precept, it has been written that the government should be able to raise the degree of people in financial terms by providing the needs of society equally and able to provide rules that can create welfare in all levels of society without discriminating one with another. It is also written in Islam that the resources within a state are entrusted from Allah to all mankind. The main driving force of the economy is cooperation, and Islam rejects the accumulation of wealth that is only controlled and benefiting certain parties only. Ethical behaviour is suggested to be a prescriptive value that is normally embedded in one's character and ethical values such as truthfulness, honesty, justice, and fairness are not inherited but need to be nurtured (Mohd Nor, 2012).

The definition of accounting based on the precept "Social Justice for the Whole People of Indonesia" is the process of balancing the physical and spiritual needs of mankind in terms of financial activity to build populist economy.

"O you who believe, be you one who upholds justice, be a witness for God, though against yourself or your father's mother and your brothers. So do not follow your passions so you do not do justice. And if you turn back justice or refuse to be a witness, then surely Allah is the Knower of what you do." (Quran An Nisaa: 135).

The occurrence of capitalism in urban society with the economic system that occurs gives the right of individual freedom in it to implement the wheels of the economy, such as producing goods and services, sell or market and distribute. The economic system that follows the Shariah parameters which ought to accomplish the objective of social and economic justice (Chapra, 1975; Shiddiqy, 1976) (Ahmad, 1981).Whereas within this system, every individual is free to compete without thinking about the circumstances surrounding them, because they are only thinking of ways to make the most profit. In the life of capitalism, every individual is free to compete in order to win free competition in various ways. The government should be able to participate in economic activities by taking a role fairly. This has been arranged in the fifth precept of Pancasila which is the process of balancing the physical and spiritual needs of human beings in terms of financial activities to build a populist economy. It has also been regulated in Islamic Religion that we need to be fair in economic activities within a society, in order to create a system of economy which is capable of prospering all the people within it, not just certain parties.

Based on the result of the research on each precept, it can be obtained a conclusion that the definition of accounting in the perspective of Pancasila is human responsibility to God through humanizing human beings in the midst of the development of urbanization in Indonesia; creating a fraternal spirit among people in it; elevating people to an unqualified justice for anyone in the country; as well as balancing the physical and spiritual needs 
of human beings in terms of financial and economic activities that can advance the nation's life to be better and prosperous for all communities in it. Accounting in the perspective of Pancasila does not only emphasize the material element alone.

\section{CONCLUSIONS}

Pancasila is human responsibility to God through humanizing human beings in the midst of the development of urbanization in Indonesia; creating a fraternal spirit among people in it; elevating people to an unqualified justice for anyone in the country; as well as balancing the physical and spiritual needs of human beings in terms of financial and economic activities that can advance the nation's life to be better and prosperous for all communities in it. Accounting in the perspective of Pancasila does not only emphasize the material element alone. If the application of this accounting is fully interpreted, the creation of an accounting paradigm will not only focus on the mind on self-interest, but also note the interests of God and fellow creatures that exist on earth this. For future researches, this research can be further developed with more complete and accurate data, so this research can provide benefits for us all.

\section{ACKNOWLEDGEMENTS}

We would like to thank reviewers for comments and suggestion regarding to turbine engine analysis. We also like to thanks for support from Department of Accounting of Airlangga University.

\section{REFERENCES}

Achsin, M., 2006. Menyingkap Dampak Positivisme Terhadap Esensi Penciptaan Manusia. Jurnal TEMA, 7(1), 35-49.

Ahmad, K., 1981. Economic development in an Islamic framework.

Ali, S., 2013. Prediksi perilaku ramah lingkungan yang dipengaruhi oleh nilai dan gaya hidup konsumen. JURNAL ADMINISTRATIO, I(1).

Armawi, A., 2007. Dari Konsumerisme ke Konsumtivisme (Dalam Perpektif Sejarah Filsafat Barat). Jurnal Filsafat, 17(3), 314-323.

Bungin, B., 2005. Analisis Data Penelitian Kualitatif, Raja Grafindo Persada. Jakarta, Edisi 1.

Burrell, G., Morgan, G., 2017. Sociological paradigms and organisational analysis: Elements of the sociology of corporate life. Routledge.
Chapra, M. U., 1975. Objectives of the Islamic economic order, Islamic Council of Europe.

Fishkin, J. S., 1991. Democracy and deliberation: New directions for democratic reform, Yale University Press.

Heath, C., 1995. Escalation and de-escalation of commitment in response to sunk costs: The role of budgeting in mental accounting. Organizational Behavior and Human Decision Processes, 62(1), 3854.

Heryanto, J., 2005. Pergeseran nilai dan Konsumerisme di Tengah Krisis Ekonomi di Indonesia, Nirmana, 6(1).

Iqbal, Z., Mirakhor, A., 2011. An introduction to Islamic finance: theory and practice (Vol. 687). John Wiley and Sons.

Jacoby, J., Szybillo, G. J., Berning, C. K., 1976. Time and consumer behavior: An interdisciplinary overview, Journal of Consumer Research, 2(4), 320-339.

Jati, W. R., 2015. Less Cash Society: Menakar Mode Konsumerisme Baru Kelas Menengah Indonesia. Jurnal Sosioteknologi Lembaga Ilmu Pengetahuan Indonesia (P2P-LIPI), 14(2).

Kahneman, D., Tversky, A., 1984. Choices, values, and frames. American psychologist, 39(4), 341.

Ludigdo, U., Kamayanti, A., 2012. Pancasila as Accountant Ethics Imperialism Liberator. World, 2(6).

Mohd Nor, S., 2012. Integrating moral in a dynamic model of corporate social responsibility in Islamic Economics and Finance.

Mulawarman, A. D., 2014. Nyanyian Metodologi Akuntansi Ala Nataatmadja: Melampaui Derridian Mengembangkan Pemikiran Bangsa "Sendiri". Jurnal Akuntansi Multiparadigma, 4(1).

Rosida, I., 2014. Hasrat komoditas di ruang urban Jakarta: sebuah kajian budaya. Buletin Al-Turas, 20(1), 57-66.

Shiddiqy, M. N., 1976. Muslim Economic Thinking, A Survey of Contemporary Literature, dalam buku. Studies in Islamic Economics, International Centre for Research in Islamic Economics.

Sitorus, J. H. E., 2015. Membawa Pancasila Dalam Suatu Definisi Akuntansi. Jurnal Akuntansi Multiparadigma, 6(2), 254-271.

Wallerstein, I., 1974. The rise and future demise of the world capitalist system: Concepts for comparative analysis. Comparative studies in society and history, 16(4), 387-415.

Weber, M., 2002. The Protestant ethic and the" spirit" of capitalism and other writings, Penguin. 